\title{
Predictive variables influencing students participation in combative sports in Nigeria
}

\author{
EKURI, P. K., EDIM, M. E., ODOK, E. A. \\ Department of Human Kinetics and Health Education, Faculty of Education, University of Calabar, Calabar, Nigeria \\ Email address: \\ edimmoses@yahoo.com (EDIM M. E.)
}

To cite this article:

EKURI, P. K., EDIM, M. E., ODOK, E. A.. Predictive Variables Influencing Students Participation in Combative Sports in Nigeria. International Journal of Secondary Education. Vol. 2, No. 3, 2014, pp. 48-51. doi: 10.11648/j.jjsedu.20140203.11

\begin{abstract}
This paper tries to examine some variables that influence students' participation in combative sports in Nigeria. The study looked at the effect of coach-student relationship, school influence and peer influence on students' participation in combative sports. The results of the findings show that coaches-students relationship has significant influence on students' interest in combative sports, school and peer group also have significant influence in students participation in combative sports. Some recommendations such as combative sports should be introduced in all levels of the educational system. This will encourage large number of participants in these sports; that even at the community levels, combative sports should be introduced to help in instilling discipline and respect for law and order. It will enhance in the maintenance peace and unity in the community.
\end{abstract}

Keywords: Combative Sports, Participation, Coach/Students Relationship, School Influence, and Peer Influence

\section{Introduction}

The demand for various physical and mental training programmes suited for the active development of the body and mind has informed many a people to engage in combative sports and other forms of physical exercises thereby improving their individual life style. Sports participation is an important part of maturation, a period during which participants develop their character and learn to handle stress and difficult situations in life's journey. Sports participation enables one to acquire discipline while meeting challenges or facing other individuals physically, mentally, socially and emotionally (Wang, 2001). Lidor, Melnik, Belkevltz, Arnon and Falk, (2005) observed that majorly, combative sports have some rules of conduct and honor which must be observed by everybody wishing to practice combative sports. These rules of conduct and honor include respect of friendship, respect and obedience to one's friends, parents and elders, courage in battle, avoiding unnecessary violence, loyalty to the nation, respect to the teachings and codes of combative sports (rules, regulations and laws), faithfulness to friendship and unwarranted killing (especially with an untrained persons), (Cohen, 2003).

It is however observed Deafs Aikidoits Society, (2004) that many people still view sport as repetitive aerobics, but for a growing number of people, the term now represents the ultimate challenges to develop their minds, bodies and self images. It is however observed that participating in combative sports help in making one physically strong, improve self defense from dangerous situation, having relaxed mind, and resistance to some form of sexual assault. In recent times most people dedicate themselves to physical training in a variety of ways through various combative sports for strength, endurance, emotional wellbeing and self defense (Mendenhall, 2006).

Chan, Pieter, and Moloney, (2003) found out that globally the health and physical fitness of every citizen is a fundamental human right of every individual and regular hard exercise is compulsory for anyone who intends to remain physically fit. It is discovered that there is a growing awareness among Nigerians towards sports participation for the youths, children, the aged and the handicapped in various sporting activities. The Federal Government of Nigeria through its relevant ministries have understood that health for all is a national asset and it is an acceptable fact that sports activities be it traditional or conventional, has a profound relationship to health, good working condition, happiness and good 
citizenship, (Dunlap, 2004, National Organization On Disability 2004 and Mendenhall, 2006). It is in this light that Mendenhall, (2006) concluded in his work that sports carried out in the form of physical exercises contribute greatly to physical fitness which is the most essential boaster to a healthy living. This is so because, the development of the physical wellness of the individual is both physical, emotional, social and mental. With these achievements, one can begin to feel free and interact with peers and friends from other social ethnic groups, with the same sense of responsibility and justice (Ampongan and Pieter, 2005). This has also been judged world over as an anodyne to a healthy world health and relationships.

This led Yudansha, Kobujitsu, Karate-Doh Federation; Martial Arts for the Disabled (2004) to observe that participation in combative sports or martial art serves as an appetizer to further participate in other sports through getting ready to play. When people come together to play, they share a common feature together and also have a feeling of togetherness, friendship and comradeship, thereby reducing violence and conflicts among participating teams and members. Li, (2001) found out that combative sports encourage the growth of team spirit and friendship among those participating, officiating and supervising, it is this aspect of combative sport that influences the relationship between coaches, peers, family members and other participants in the sports.

Lidor, et al (2005) observed that peer influences have severally been adduced as reasons why some students participate in certain activities, conduct or behaviors. A lot of studies have shown that so many influencing factors have been displayed by certain persons in the lives of adolescents and students. Some students see their parents, teachers, peers and other persons as their role models and mentors, while others see them as their icons and learn to live and act like such persons. In situation like this, we could say these persons in the lives of these people are influencing factors in their lives, (Melhim, 2001, Miller, 2003 and Mendenhall, 2006). Some studies looked at the influence of peers, parents and friends as motivating factors why some students or children participate in violent act against their peers, neighbours and other school mates, while another studies reported that some students became smokers because the friends they walk and play together are smokers and they were influenced to smoke because their friends do so (Lan, 2000, Hong, 2000, Yeung, 2001 and Van De Sandt, 2004).

Shapira, (2001) was however of the view that most people with migraine and other severe head trauma participate in combative sport because it helps in reducing the strain. When one is stressed, one becomes emotionally unstable and perturbed, in situations like this, friendship could reduce the strain in the brain thereby avoiding situations that are either violent from such emotions or situation could be minimized and managed because of the discipline acquired during training in combative sports. Melhim, (2001) however listed peer influence, self defense, and keeping fit as the major reason why people join combative sports and other general sports.

Since most persons now participate in combative sports, why do they participate and what are the reasons or influencing factors that orchestrated their participation in combative sports? This research therefore is designed to assess the factors that make students participate in combative sport in Nigeria. Looking at this situation critically, it could be that the type of people one admires push people to want to act like them or does participation in combative sports bring about the development of cordial relationship, team and friendship spirits and comradeship, is it possible that this team spirit is what influenced the participation of some people in combative sports?

\section{Methodology}

Using the survey research design for the study; the researcher sampled a total of 150 Judo and 120 Taekwondo and their coaches from both male and female black belters, kyus/ Keups and their coaches training in Judo and Taekwondo across Cross River State from the periods between 2010-2013. Stratified random sampling technique was used to select the sample for the study. A well structured questionnaire was the instrument used for data collection with items covering the following influencing factors like: parent's influence, school and learning environment, peer influence, students and coach relationship as possible factors influencing student's participation in combative sports. The reliability and validity of the instrument for fitness for collecting data for the study is the Cronbach alpha reliability test that was used to ascertain the instrument's validity and reliability, this procedure is to determine the internal consistency of the test item. The Cronbach alpha reliability estimate (r) 0.89 , was gotten indicating that the instrument was therefore highly reliable, while a validity coefficient index of 89 percent was also recorded showing very high validity. This implies that if the same instrument is used over and over again, the possibility is that the instrument will give $89 \%$ accurate and valid data over a hundred trials. These instruments were personally administered by the researchers and three trained research assistants and same were collected directly from the respondents. The data generated from the field using the instrument was then coded and subjected to the SPSS version 15 for Chi square and simple percentage analysis, the result is as shown on Table 1. 
Table 1. Chi square analysis of some predictive variables influencing students 'participation in combative sports in Nigeria

\begin{tabular}{|c|c|c|c|c|c|c|c|c|c|}
\hline \multicolumn{6}{|l|}{ Judo } & \multicolumn{4}{|c|}{ Taekwondo } \\
\hline Variables & Response & Freq & $\%$ & $\mathrm{X}^{2}$ & Remark & Freq & $\%$ & $\mathrm{X}^{2}$ & Remark \\
\hline \multirow{3}{*}{$\begin{array}{l}\text { Coach/student } \\
\text { relationship }\end{array}$} & Agree & 140 & 93 & \multirow{3}{*}{112.6} & \multirow{3}{*}{ Sig. } & 113 & 94.2 & \multirow{3}{*}{93.6} & \multirow{3}{*}{ Sig. } \\
\hline & Disagree & 10 & 7 & & & 7 & 5.8 & & \\
\hline & Total & 150 & 100 & & & 120 & 100 & & \\
\hline \multirow{3}{*}{ School influence } & Agree & 93 & 62 & \multirow{3}{*}{8.6} & \multirow{3}{*}{ Sig. } & 54 & 45 & \multirow{3}{*}{1.2} & \multirow{3}{*}{ Not sig. } \\
\hline & Disagree & 57 & 38 & & & 66 & 55 & & \\
\hline & Total & 150 & 100 & & & 120 & 100 & & \\
\hline \multirow{3}{*}{ Peer influence } & Agree & 67 & 44.7 & \multirow{3}{*}{1.7} & \multirow{3}{*}{ Not sig. } & 59 & 49.2 & \multirow{3}{*}{.033} & \multirow{3}{*}{ Not sig. } \\
\hline & Disagree & 83 & 55.3 & & & 61 & 50.8 & & \\
\hline & Total & 150 & 100 & & & 120 & 100 & & \\
\hline
\end{tabular}

\section{Result}

On whether coach/student relationship is a significant determining factor for participation in combative sport, $93 \%$ of the respondents (140) in judo agreed, while $7 \%$ representing 10 respondents disagreed. In Taekwondo, $94.2 \%$ of the respondents representing 113 agreed, while 7 respondents $(5.8 \%)$ disagreed with the majority. Judo and Taekwondo had a calculated chi square value of 112.6 and 93.6 respectively, thus indicating that the cordial relationship between coaches and students attract significant participation in combative sports.

On whether school programmes significantly correlate with participation in combative sports, $62 \%$ of the respondents in Judo agreed, while $38 \%$ of the same group disagreed. Those in Taekwondo indicated that $45 \%$ agreed, while $55 \%$ disagreed that they were not influenced by the school programmes to join combative sports. The calculated chi square value of 8.6 and 1.2 for Judo and Taekwondo were recorded accordingly. The calculated chi square value of 8.6 for Judo was significant, while the calculated chi square value for Taekwondo of 1.2 is not significant. This therefore means that the Judokas were significantly influenced by their school programmes while the Taekwondoist were not significantly influenced by their school programs to participate in this sport.

Result on peer interaction depicts that $44.7 \%$ of Judokas agreed that peer interaction influence their participation in the sports. Most of the respondents (55.3\%) said they were not influenced by peer interactions. 49.2\% Taekwondoist were attracted to the sport through peer interaction, 50.8\% of them said otherwise. The calculated $\mathrm{X}^{2}$ Judo (1.7) and Taekwondo (.033) were both not significant, this means peer interaction did not significantly influenced participation in Taekwondo.

\section{Discussion}

Majority of the Judokas and Taekwondoists were significantly attracted to martial art by the pleasant and cordial relationship they experienced between the coaches and their students. Coaches and athletes relationships have always been one of the most important topics of discussion in sports. The most desirable relationship is that in which an admired coach projects an image or role for the athletes and at the same time moulds the skills necessary for the athletes to reach their potentials. The findings on coachstudent relationship is in line with Abraham, Dyson, and Kingman, (2001) who opined that constructive relationship is important between the athletes and the coach for the achievements of peak performance.

Table 1 reveals that majority of the Judokas were significantly influenced by their school programmes while the Taekwondoists were not significantly influenced by this variable, maybe this sport was never included in the school programmes or it was never taught. In the case of Judo, its early inception than Taekwondo might be the reason it had an edge over Taekwondo. Results on whether peer interactions made significant influence on participation in martial arts shows that neither Judokas nor Taekwondoists were attracted to the sports by their peers. This is against the idea that peer interactions influence participation in sports as documented by Hartman, (2000). So if these sports were not made popular and attractive, only small number of participants will become committed to it, the possibility of peer interaction having influence on participation in combative sports is very slim. Similarly, it was also gathered that self defense and physical fitness is another cogent reason why most people participate in combative sports.

\section{Conclusion}

From the finding of this research therefore, factors such as peer influence, parent influence, coach- student's relationship, school and learning environment, amongst others are influencing factors which propel some persons to participate in combative sports. Based on this, one will be right therefore to say that people have various reasons why they participate in combative sports, and these reasons remain the motivating factors which gingers them to carry 
out these trainings for their ultimate benefits. It is therefore pertinent to state that people participate in various sports because they have their individual reason and influencing factors for such participation.

\section{Recommendations}

i. Combative sports should be introduced in all levels of our educational system; this will encourage large number of participation especially in our secondary schools.

ii. Even at the community levels, combative sports should also be introduced to help in instilling discipline and respect for law and order.

iii. Combative sports should be made a basic training sport considering the efficacy of its usefulness for friendship and cordiality development, respect for rules and authority and the training of the mind, thereby controlling stress, strain and emotions

iv. Factors influencing sport participation should also be encouraged to make more people participate in combative sports.

\section{References}

[1] Abraham, C, Dyson, R. and Kingman, J. (2001). Muscular activity of the striking leg during the martial arts front, side and turning kicks. Journal of Sports Sciences, 19, 3-84.

[2] Ampongan, C. and Pieter, W. (2005). Competition anxiety in elite Filipino taekwondo athletes. Acta Kinesiohae Universitatis Tartuensis, 10: 7-17.

[3] Chan, K., Pieter, W. and Moloney, K. (2003). Kinanthropometric profile of recreational taekwondo athletes. Biology of Sport, 20(3): 175-179.

[4] Cohen, R. (2003). Alternative medicine treatments put to test. The Houston Chronicle Publishing Company. 9 November.

[5] Deaf Aikidoists Society, (2004). Success-how to motivate, empower, and succeed as a deaf person, 19 Jan. 2004, http://www.deafaikidoistssociety.com. Dunlap, D., (2004). Attention deficit disorder in the Dojang. AOL Hometown. 26 Jan, http:/hometown.aol.com/twdiii/webpage/ADDarticle/ADD Article.htm.

[6] Hartman, C. A., (2000). Effects of T'ai Chi training on function and quality of life indicators in older adults with Osteoarthritis. Journal of the American Geriatrics Society 48.12: 1553-1559.
[7] Hong, Y., (2000). Balance control, flexibility, and cardiorespiratory fitness among older Tai Chi practitioners. British Journal of Sports Medicine 34, 1 29-34.

[8] Lan, C., (2000). Tai Chi Chuan to improve muscular strength and endurance in elderly individuals: A pilot study. Archives of Physical Medicine and Rehabilitation 81.5: 604-607.

[9] Li, J.X. (2001). Tai Chi: Psychological characteristics and beneficial effects on health. British Journal of Sports Medicine 35.3: 148-156.

[10] Lidor, R., Melnik, Y., Bilkevltz, A., Arnon, M. and Falk, B. (2005). Measurement of talent in judo using a unique, judospecific ability test. Journal of Sports Medicine and Physical Fitness, 45(1): 32-37.

[11] Melhim, A.F., (2001) Aerobic and anaerobic power responses to the practice of taekwondo. British Journal of Sports Medicine 35, 231-235.

[12] Mendenhall, M., (2006) An investigation of the impact of Buddhist martial arts as a rehabilitation intervention program to remedy emotional problems, curb aggressive tendencies, develop self-awareness, and cultivate a strong moral foundation with incarcerated juvenile delinquents. Unpublished Manuscript. Free Press.

[13] Miller, C., (2003). Popularity of Martial Arts Growth is no longer movie inspired. The Courier Journal. 26 February. http://www.courierjournal.com/localnews/2003/02/26iweek/ in022603s372488.ht.

[14] National Organization on Disability (2004) 25 March. http://www.nod.org. Office of Special Education and Rehabilitation Services. OSERS: Programs and Projects. 12 Feb. 2004. http://www.ed.gov.

[15] Shapira, M.Y., (2001). Tai Chi Chuan practice as a tool for rehabilitation of severe head trauma: 3 Case Reports. Archives of Physical Medicine and Rehabilitation 82.9: 1283-1285.

[16] Van De Sandt, R., (2004). Kurumaisu Jutsu: Wheelchair techniques. Fighting Art.Com Magazine. 26 Jan.http://www.fightingarts.com/content02/wheelchair_tech _1.shtml.

[17] Wang, J.S., (2001). Tai Chi Chuan Training to enhance microcirculatory function in healthy elderly men. Archives of Physical Medicine and Rehabilitation 82.9: 1176-1180.

[18] Yeung, D., (2001). Rehabilitation of patients with Rheumatoid Arthritis by Tai Chi Chuen training. American College of Rheumatology 45.6

[19] Yudansha Kobujitsu Karate-Doh Federation; Martial Arts for the Disabled, (2004) http://www.geocities.com/ykkf/content/home.htm assessed 25th June, 2013 